\title{
INDEX ACCORDING TO SUBJECTS
}

[The numbers refer to pages.]

Algebra-Invariants . Vaidyanathaswamy, R., 104.

Analysis . . . Walsh, C. E., 193, 197.

Determinants . . Turnbull, H. W., 49 : Aitken, A. C., 55 : Bell, E. T., 177 : Nassau, J. J., 189.

Differential Calculus . M'Whan, J., 68.

Differential Equations . Stewart, C. A., 94.

Function Theory . Whittaker, J. M., 47: Copson, E. T., 62, 129: Hyslop, J., 234.

Geometry, Algebraic - Baker, H. F., 19: Richmond, H. W., 31, 39 : Saddler, W., 65, 182, 204: Vaidyanathaswamy, R., 104.

Geometry, Differential . Richmond, H. W., 39: Sen, Rabindra Nath, 149: Weatherburn, C. E., 160 .

History . . . Gibson, G. A., 1, 71.

Integration, Numerical . Wolff, C. E., 139.

Integration, Theory of . Hyslop, J., 234: Whittaker, J. M., 209.

Interpolation $\quad$. Aitken, A. C., 199.

-Cardinal Function Whittaker, J. M., 41, 169.

Lamé Functions - Copson, E. T., 62.

Legendre Functions . Sircar, Hrishikesh, 241, 244.

Matrices . . . Aitken, A. C., 134, 166: Turnbull, H. W., 111.

Partial Fractions . . Turnbull, H. W., 49.

Principia Mathematica . Whittaker, J. M., 47. 


\section{The following Presents to the Library have been received, for which the Society tenders its grateful thanks.}

1. Abhandlungen aus dem Mathematischen Seminar der Hamburgischen Universität.

2. Acta Academiae Aboensis.

3. Acta Universitatis Asiae Mediae.

4. Anais da Faculdade de Sciências do Porto.

5. Annales de la Faculté des Sciences de Marseille.

6. Annales de la Faculté des Sciences de l'Cniversité de Toulouse.

7. Annales Scientifiques des Institutions Mathematiques Savantes de l'Ukraine.

8. Annales de la Société Polonaise de Mathematique.

9. Annales Scientifiques de L'Université de Jassy.

10. Annals of Mathematics.

11. Nieuw Archief voor Wiskunde.

12 Arkiv für Matematik, Astronomi Och Fysik.

13. Boletin de Seminario Matemático Argentino.

14. Bulletin of the American Mathematical Society.

15. Bulletin of the Calcutta Mathematical Society.

16. Bulletin de la Société Mathématique de France.

17. Bulletin de la Société Physico-Mathématique de Kasan.

18. Communications de la Société Mathématique de Kharkow.

19. Bulletin Mathématique de la Société Roumaine des Sciences.

20. Contribucion al Estudio de las Ciencias Fisicas y Matematicas.

21. Fundamenta Mathematicae.

22. The Mathematical Gazette.

23. American Journal of Mathematics.

24. Journal of the Faculty of Science, Imperial University of Tokyo.

25. Journal of the Indian Mathematical Society.

26. Japanese Journal of Mathematics.

27. Journal of Mathematics and Physics, Massachusetts Institute of Technology.

28. Journal de la Société Physico-Mathématique de Léningrade.

29. Kansas University Science Bulletin.

30. Lunds Cniversitets Ärsskrift.

31. Memorias de la Real Academia de Ciencias exactas, fisicas y naturales (Madrid).

32. Monatshefte für Mathematik und Physik.

33. Memoirs and Proceedings of the Manchester Literary and Philosophical Society.

34. Nachrichten von der Gesellschaft der Wissenschaften zu Göttingen (Mathematischphysikalische Klasse).

35. Nachrichten von der Gesellschaft der Wissenschaften zu Göttingen (Geschäftliche Mitteilungen).

36. Wiskundige Opgaven met de Oplossingen.

37. Proceedings of the American Philosophical Society.

38. Proceedings of the Cambridge Philosophical Society. 
39. Proceedings of the Leeds Philosophical and Literary Society.

40. Proceedings of the London Mathematical Society.

41. Proceedings of the National Academy of Sciences.

42. Proceedings of the Physico-Mathematical Society of Japan.

43. Proceedings of the Royal Society of Edinburgh.

44. Publications de la Faculté des Sciences de l'Université Masaryk.

45. Publications de l'Institut de Mathématiques de l'Université de Strasbourg.

46. Publications du Laboratoire d'Astronomie et de Géodésie de l'Université de Louvain.

47. Publications from the Massachusetts Institute of Technology.

48. Publications of the U.S. Coast and Geodetic Survey.

49. Rendiconti del Circolo Matematico di Palermo.

50. Rendiconti del Seminario Matematico e Fisico di Milano.

51. Revista de la Real Academia de Ciencias de Madrid.

52. Revue Semestrielle des Publications Mathematiques.

53. Science Reports of the Tôhoku Imperial University.

54. Sitzungsberichte der Königlich Bayerischen Akademie der Wissenschaften Mathematisch-Physikalische Klasse zu München.

55. Sitzungsberichte (Wien).

56. Sydney University Reprints.

57. Smithsonian Publications.

58. The Tôhoku Mathematical Journal.

59. Transactions of the Actuarial Society of America.

60. The University of Missouri Studies.

61. Vierteljahrschrift der Naturforschenden Gesellschaft in Zürich.

62. Warsaw Prace Matematyczno-Fizyczne.

63. Elektrostatik der Leiter-Friedrich Kotrler.

64. Compléments de Geométric Moderne-Chardes Michel.

65. Immensities of Time and Space-A. Vibert Dotglas, M.B.E., M.Sc.

66. Note on the Sum of the Signed Primary Minors of a Persymmetric ContinuantSir Thomas Muir, F.R.S.

67. Hadamard's Approximation Theorem since 1900 -Sir Thomas Mrir, F.R.S.

68. Note on Hyperorthogonants-Sir Thomas Mcir, F.R.S.

69. The Theory of Hessians from 1883-1914.-Sir Thomas Muir, F.R.S.

70. Essai d'un cones de haute mathématique mené par une méthode laboratorie et par groupes dans l'Université d'etat à l'Extrême-Orient-A. B'́kEREFF.

71. Sur la transformatum de l'équation générale d'une courbe du second ordreN. AgronomuF.

72. Résultats des travaux sur mars en 1924-5--U. I. Toмнукк.

73. Sur l'Integration des Equations Differentielles aux Dériveés Partrelles avec Plusieurs Variables Dépendantes-M. KonIrsky.

74. Quelques applications de l'Hydrodynamique-M. JACQves Bencie.

75. Questions d'Arithmetique-B. Niewerglowski.

76. On the Evolution of the Stars-C. G. Aввот. 